\title{
Sabores y Saberes Para La Educación: Propuesta Metodológica integral Para La Alimentación ${ }^{1}$
}

\author{
María Fernanda Acosta Altamirano \\ Docente-investigadora \\ Universidad Nacional de Educación (Ecuador) \\ Université Côte d'Azur (France)
}

\begin{abstract}
Teaching is a live practice that should be thought continuously. Research is an important support for this activity. Doing investigation, it is possible to generate results and tools that can be used in the classroom. From this dialectics relation between practice and theory (practice that is rethought and theory that is experienced), this methodological proposal was born. This does not pretends to be a mandatory guideline due to it obeys to a particular context from the National University of Education in Ecuador (UNAE from now), but this proposal looks to generate questions about how to study this teaching processes taking children nutrition into consideration. This article presents an integral methodology of teaching about feeding and food, it begins from a transdisciplinary point of view that goes beyond the calorie intake of children, because it understands feeding and food as an integral process that involves not only the physiological needs but also sociocultural and emotional factors. Additionally, this document relates teaching as a practice when doing the research with the participation of the community. This methodological proposal is not thought as a mandatory modal but it looks for giving arguments to enrich the analysis for the early education. Doing so the socalled 'mealtime' is lived as a moment of joy, respect and affection that goes beyond the act of eating.
\end{abstract}

Keywords: early education, transdisciplinarity, active hearing, food heritage, integral educations, theory, practice, memory, and teaching.

\section{Introduction}

Mealtime, in the early childhood education (one to five years old) is an important moment of learning in which children build their habits and their initial patterns linked to food. The curriculum of UNAE (Universidad Nacional de Educación/National University of Education) focused on this early education includes topics such as health, safety, children nutrition and family environment. From the perspective of the University, these subjects must surpassthe concepts of calorie intake and balanced diet: feeding is an integral process that involves physiological, socio-cultural and emotional aspects that are needs of each infant. Taking this into consideration, this article is a proposal of a methodology of integral education focused on food, which is built on a transdisciplinary approach. This last combines the process of the research and the participation of the community in the teaching practice.

Additionally, this methodology is an exercise of dialectics between theory and practice. This aspect proposes a relation in which it is possible to 'theorize the practice and experiment the theory', which goes from active and meaningful learning to a reflective practice. To this end, this article is focused on presenting a research project on the topic of ancestral knowledge and education, and also its connections with the practice of teaching in the university. Next, this document presents teaching in relation to a transdisciplinary approach that conduces to the reflection of nutrition from different disciplines connected to each other like: nutrition, psychopedagogy, anthropology and sociology. Also, it presents their connections with the research project, which leads to build the discussion on the mentioned issues above.

\section{Taday: A Historical Community}

The research project entitled 'Ancestral Knowledge, Technological and Social Innovation of Related Farmers form the Community of Cañar in a Intercultural and Interscientific dialogue, enclosed in the conceptual framework of the Ecology of Knowledge and a New Pedagogic Model' was approved by the UNAE in July 2016. Currently, this project is implementing the second stage named "Ancestral Knowledge and Educational, Social and Technological Innovation". The main objective of the first two stages of the project is to revitalize the collective memory, based on the collection and revaluation of ancestral and traditional knowledge of the communities. Besides, this works aims to support the processes of strengthening the local identities. To UNAE, the focus of the 'Participatory Action Research' is essential.

${ }^{1}$ FER, SUGIERO QUE AQUI SE RESUMA DE DONDE SALE EL PROYECTO. TE AHORRARIA ESPACIO Y DE ENTRADA LE DEJAS CLARO AL LECTOR EL CONTEXTO DEL MISMO 
This aspect states that the process of research itself must be always an activity among the researchers and the social actors of the community who are involved in the project. As a result, the findings of this process must be returned to the community in order to promote a social transformation from the participants. In order to understand the specificities of this research, it is necessary to understand the socio-cultural context of Taday first. The parish of San Andrés in Taday, belongs to the Ecuadorian province of Cañar. Data of the $\mathrm{V}$ census of population and IV of housing of the National Institute of Statistics and Census, INEC, show that in 2001 in Cañar there were 206.981 migrants (the majority went to the United States or Spain as destinies), which locates it as a province with the greatest impact of the migration because of the percentage of migrants in relation to the rest of the population from Ecuador (Ochoa Moreno, 2010, p.73). This figure is officially registered; however the fact that it is considered as irregular migration is not the only explanation of this migration but there are many more cases that are not officially reported.

These migratory flows caused a 'migratory syndrome' (Herrera y Martínez), which modified the daily basis and some socio-cultural representations; for example: changes in the consumption patterns of the families that received the remittances from their relatives; imaginary about the lives of migrants in destination countries, modifications to the local architectural landscape and others, which are all elements that affect the beliefs, values and aspirations of the local population (Herrera \& Martínez, 2002, pp. 7-8).

In this context, this research project is focused on revitalizing the knowledge connected to food and memory. Being a rural community, much of their daily activities are linked to agriculture. This activity obeys to certain traditional practices correlated to the cañari agricultural and festive calendar (appendix 1). During the first phase, UNAE supported the work of the local government in the creation of 25 family chakras and two more chakras in educational institutions (at the Vicente Rocafuerte School and the Andrés Guritave School). After this process, in-depth interviews were conducted with a dozen qualified informants to identify the nutritional changes in the area and to understand its impact on the local agriculture. Another stage developed three participatory workshops to raise the agricultural calendar of Taday, which only existed as part of the oral history of the members of the community. This information allowed graphing the calendar. This mentioned document is essential to help to the preservation of the memory of people from Taday that is linked to the agricultural practices. The following section will describe the results of these two processes mentioned.

\section{Consequences of migration in Taday's food production and eating}

From the narratives of the informants, it was possible to identify some relevant data in relation to the intergenerational change in Taday's feeding that should be explained by migration. Three decades ago, each family organized a minga ${ }^{2}$ with the ancestral sow system called yunta (a way to plow in which two people guide two oxen over the land). One of the informants, Mr. Lasso, remembers that they did mingas with up to five couples of oxen. Because of migration, this reality changed due to the number of the members of the family reduced, and there were not enough people for the mingas and/or conduct the oxen. Consequently, farming in Taday was affected.

Additionally, new generations replaced the consumption of traditional dishes that were based on grains such as vidashunku (a soup of a variety of corn with beans and pork) and other soups based on endemic grains or vegetables. Nowadays, they choose a different kind of food like 'arroz con pollo' (a dish made of rice and roaster chicken). Markets and fast consumption were established. So, as a result, new generations preferred to prepare coffee with instant coffee than grinded coffee beans. This change is considered a risk for the traditional kitchen in Taday. Since there is no intergenerational transmission of the recipes, these could be a factor that interrupts the preparation of traditional dishes and later the knowledge of the creation of the dishes could be lost.

This modification in food has also altered the agricultural production. Because of there are certain dishes that are no longer prepared, the seeds that were the main ingredient of them are no longer planted. The collected testimonies showed that some species of potatoes and lentils do not have enough seeds to be sown. Moreover, informants reported the loss of at least four varieties of potatoes (such as Suscaleña, Cubeña, Kuripamba, Bolona, Chio, Teresa Chío, Chío Negra, Bolona Negra, Chuchispa) and also they reported the loss of some varieties of lentils (C. Lasso, interview, March 23, 2017).

Recorded data showed that it is vital to work on the concept of food as heritage in the area of formal education and, doing so, revitalize the memory of culinary practices in the parish of Taday. Flavors hold an important part of the traditional knowledge of the families of the community. Each ingredient and the preparation of the dishes are part of the memory of every town and legacy. The knowledge and the heritage about food and feeding is part of the living culture of this community.

\footnotetext{
${ }^{2}$ Minga is a collective work.
} 
For this reason, this study includes the pedagogical visit of the students of the UNAE to Taday (students go to these visits with guided questionnaires for interviews elaborated by them). Students usually compare this experience with previous works they did in similar practices in which children of some educational institutes often bring 'junk food' (French fries, nachos or other kind of food)as snacks. This kind of food has poor nutritional value.

\section{Elaboration of the Agricultural and Festival calendar of Cañar (appendix 1)}

As it was mentioned before, it was possible to graph the agricultural and festive calendar in Taday from three workshops with the community. During this stage of the research, the collected data was differentiated for each month over one year. In Taday, activities related to agriculture are closely linked to natural phenomena: it is propitious to have the right climate to be able to sow, so that the products can grow in time for harvest. This scheduling of the agricultural activities is the conservation of some ancestral knowledge, and it is part of the knowledge of people from Taday and their memory.

The agricultural and festive calendar is based on the relation between climate and agricultural activities. In addition, it includes the religious celebrations that have dishes traditionally prepared for these rites. There are dialectical relationships between these four elements: the land and its management is directly associated with a sacred ritual; for example, the celebrations of San Andrés's festivities (saint of the community),Santa Teresita or San Francisco in time of the sowing. The whole ritual will be focused on asking to these divinities their blessing for a good harvest. Meals will be special for these holidays, and they will be based on the seasonal products: in times of harvest meals with fresh grains and later with dry grains. After organizing the information it was given to the parish government that drew up the graph of Taday's agro forestry calendar (appendix 1). This material permits to have guidelines for planting periods and harvesting according to the educational spaces that have chakras (this data will be presented in the last chapter of this article).

Photo1: Second Workshop: constructing the agronomic calendar of Taday 05/2017

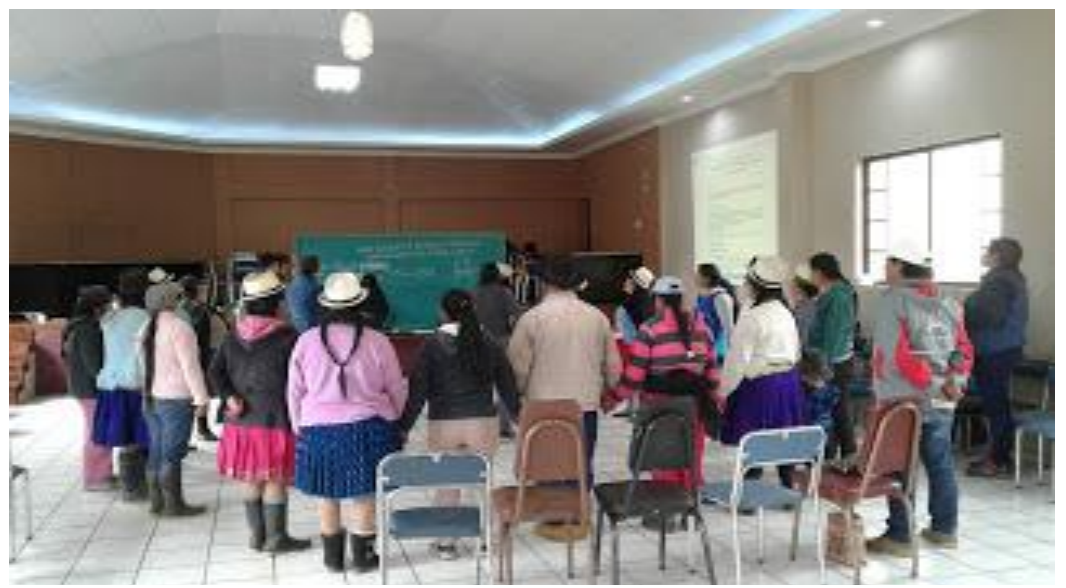

Source: María Fernanda Acosta

Photo 2: Second Workshop: constructing the agronomic calendar of Taday 05/2017

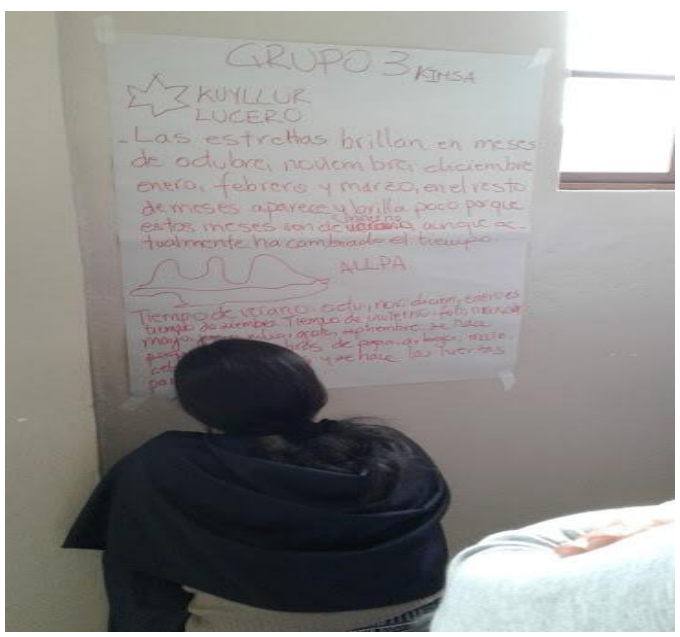

Source: María Fernanda Acosta 
In the posterior stage of the research project, a one-week fieldtrip was planned with the students of the UNAE from different departments of the university. The objective of this process looks to allow students to get involved in the problem exposed and develop their skills as researchers in order to create a research group.

\section{Flavors from the classroom towards knowledge}

In Ecuador, initial education covers the first five years of life. After this period of time, the infant becomes part of the first level of basic education. In the Early Education Course, UNAE has a class named 'Health, Safety, Children Nutrition and Family Environment', which is taught in fifth semester. At this point, it is necessary to ask how do we teach about food from an integral perspective. Caloric intake and balanced diet is an important part of the contents; however, children's 'mealtime' is important to take into consideration too because of it is a topic that involves emotional, social and cultural factors.

The schedule for the first classes included nutritional and botanical classifications of food, based on an active education methodology in which students investigated and discovered different categories related to nutrition. Then, students classified the food they brought to school as a practice of what they learned. These elements are essential to identify what is considered to be a balanced diet and the recommended portions for children.

\section{Photo 3: Class on botanical classification of food, UNAE 03/2017}

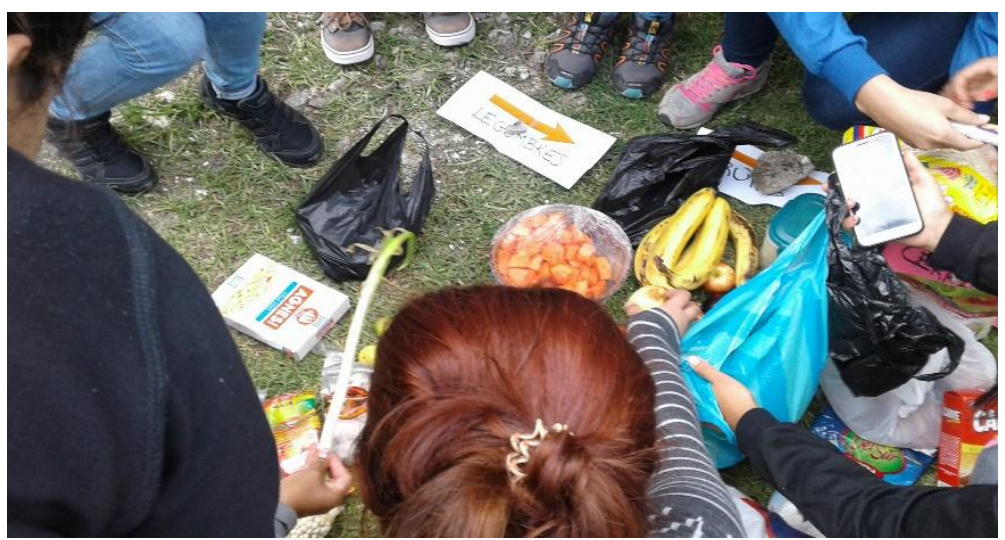

Source: María Fernanda Acosta

\section{Photo 4: Class on botanical classification of food, UNAE 03/2017}

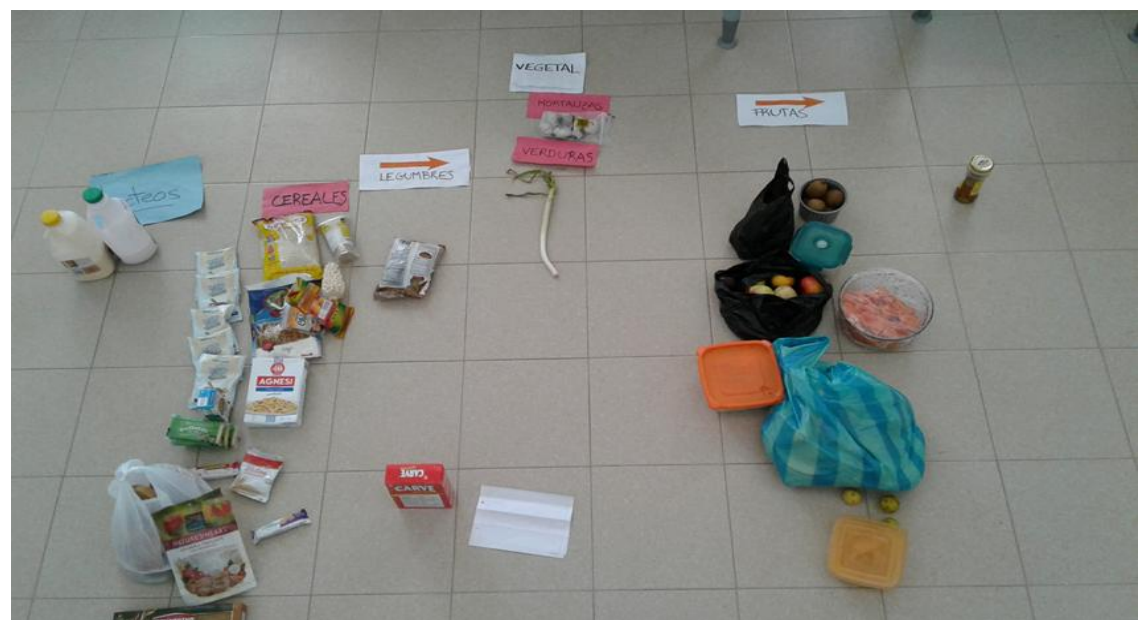

Source: María Fernanda Acosta

The study of the caloric intake must consider cultural, emotional and social aspects to create a complete vision about feeding. From the psychological perspective, an important amount of literature related to this discussion was considered, emphasizing the active listening of each child at mealtime. It is important to say that behind a lack of appetite, there are a lot of factors that can hide a difficult change in a child's life: a disease (flu, diarrhoea, and indigestion), a separation, a sadness, a grief. There is no need to reprehend a child to eat, what it is important is to be able to listen to what children have to say with or without words but by their attitudes, tears or complaints. Understanding that this refusal to eat expresses their emotions: anger, frustration, sadness (Acosta Altamirano, 2017) is essential. In these cases, professionals must work with the family to understand the familiar context and a possible 
pressence of problems. It is essential that teachers of early childhood education understand that the time for eating is a social learning space in which the basic dietary habits of children are emerging - a child establishes a friendly relationship with food at the time of feeding in order to make this as a pleasant moment (Ibid., 2017).From an anthropological methodology, every semester students have a visitation to Taday for which students have to read and analyze topics such as: the impact of the food change in the last generations, a culturally adequate diet (balanced and in which traditional recipes are resumed), food security and sovereignty, use of genetically modified organisms and pesticides in agriculture, long and short circuits of commercialization of products and food patrimony of a community in advance.

For this visit, students build a questionnaire based on the work done in classes that will be used to interview people from the chakras, school gardens and also familiar gardens. The results are exchanged in a plenary to be fully analyzed in clases.

Photo 5: Pedagogical visit to the chakra of the Vicente Rocafuerte school, Taday 11/2017

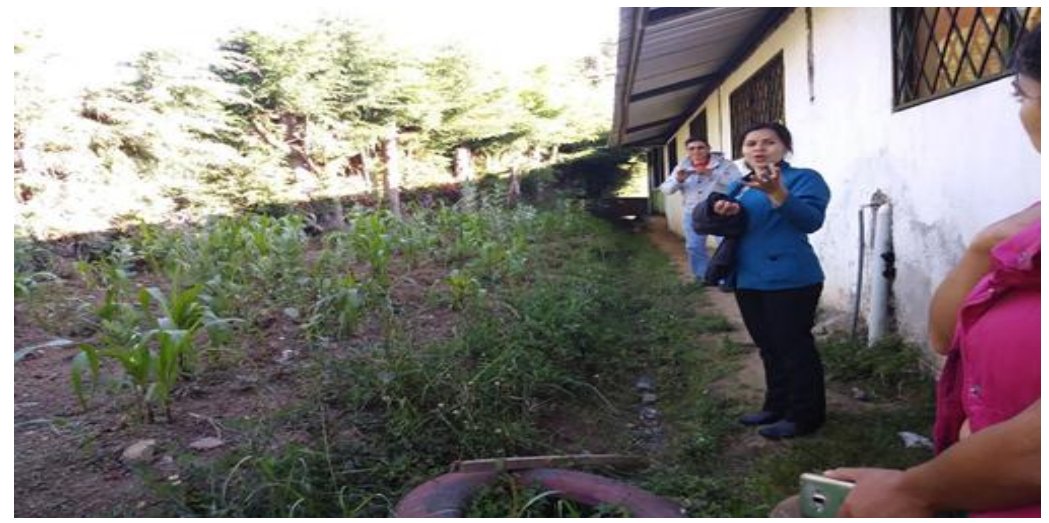

Source: María Fernanda Acosta

Photo 6: Pedagogical visit to a chakra and family garden, Taday 11/2017

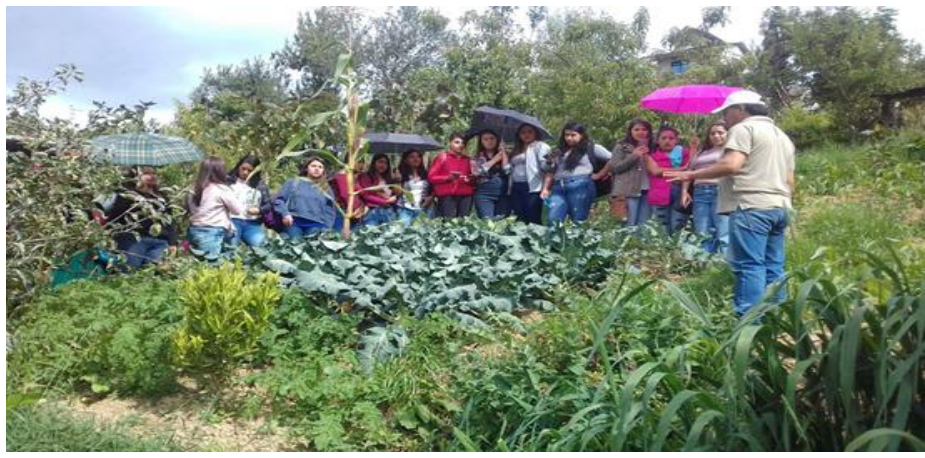

Source: María Fernanda Acosta

Photo 7: Visit to the garden of the Vicente Rocafuerte school, Taday 11/2017

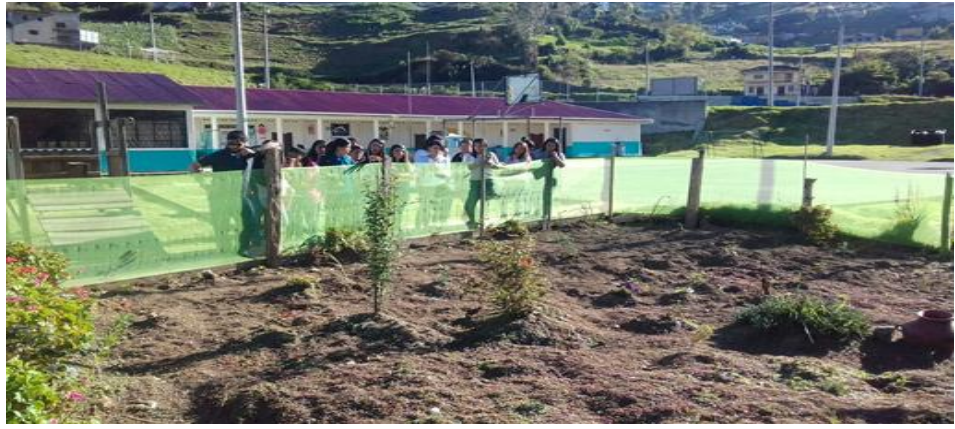

Source: María Fernanda Acosta

Finally, to address the issue of food in early education, the key actors are families because these social space is where habits are created and reinforced. For this reason, during the semester, workshops for parents were given in the pre- 
professional training schools of the students. These workshops are fully prepared by themselves with the accompaniment of the teacher. Workshops are elaborated from a constructivist methodology and meaningful learning. Each theoretical element has been previously experienced by parents. In this way, in the educational centers and at homes, there is the same information and permanent approaches at mealtimes. This subject seeks to generate a panoramic reflection and integrate the subject of food from different approaches. The feeding of children in the early education must be taught from a transdisciplinary perspective that enriches the student at different levels.

\section{Discussion: 'Theorize the practice and experience the theory'}

The proposed methodology seeks to integrate various elements of the academic world and make different perspectives dialogue.

\section{From the subject 'Health, Safety, Children's Nutrition and Family Environment'}

To begin, the subject of 'Health, Safety, Children's Nutrition, and family environment' is at the intersection between the classes within UNAE research project 'Ancestral Knowledge and Educational, Social and Technological innovation' and the connection with the community. These three areas constitute the essential elements on which the Ecuadorian Higher Education system is built. There is a reflection that is enriched by the theoretical readings from the classes and is complemented at the time of the pedagogical fieldtrip in Taday. The theory of this subject goes through different disciplinary approaches ranging from psychology, systemic and nutritional-botanical, sociological, pedagogical or anthropological approaches. This combination of perspectives generates transdisciplinary dynamics in which students construct elaborated thinking and a position from various perspectives in relation to infant feeding.

The research project also provides elements to analyze the problems related to food in a strong way. This contact, with a context in the rural area, complements the knowledge acquired from the observations in educational centers in urban areas during pre-professional practices. Within this learning are the different relationships that children build with nature in these two different contexts: while in one environment children are aware of the caring of plants, in urban contexts, children have less interaction with their natural environment. These observations generate patterns and reflections on their own teaching practices. Problems related to cities are different from those that occur in the countryside. However, the reflections are complementary and enrich the panorama of reflection, such as the growing consumption of fast food or the change in food in recent decades, resulting on a reduction in the consumption of their local dishes. After analyzing the different angles that make up the feeding of the infant, students give a workshop for parents. They make the connection with the community this way. This activity aims to generate a reflection on: balanced and culturally appropriate food, active listening at the time of eating, and the creation of healthy eating habits in a calmed environment. It is intended to generate a transformation in the practices and representations about food in order to build the foundations of adequate nutrition in children. At the pedagogical level, this course is significantly based on constructivist learning, in which the theory is experienced in the pedagogical fieldtrip to Taday, in the preprofessional practices and in the workshops with parents. These experiences are the foundations of the students learning in the class, which allows to study the experiences and later return to a theoretical analysis of reality.

Table 1: Integral pedagogical methodology for the subject "Health, safety, child nutrition and family environment", 11/2018
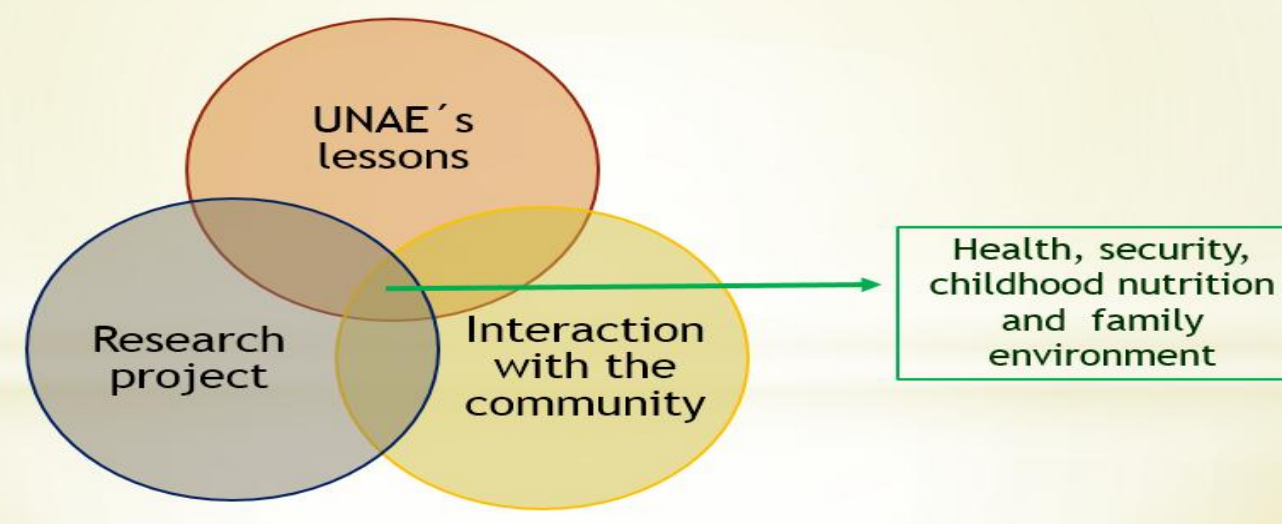

Source: María Fernanda Acosta 


\section{From the research project 'Ancestral Knowledge and Educational, Social and Technological Innovation'}

From the point of view of the research project there is also a dialectical relationship between theory and practice. The visibility of the problematic around flavors of food and the knowledge it involves generates a process of theoretical research that is reflected in the preparation of the interview guidelines and fieldwork. Once in practice, these same inputs help to rethink and reformulate the following research questions. The material resulting from this research will have three purposes: scientific production, which in turn will be a reflection material for the course; pedagogical manuals to concretely generate activities that encourage the revitalization of memory in Taday; and the intergenerational transmission of knowledge in educational contexts and the production of documents that can enrich the public educational policy of the country.

Table 2: Dialectical relationship between teaching practice and research, 01/2019

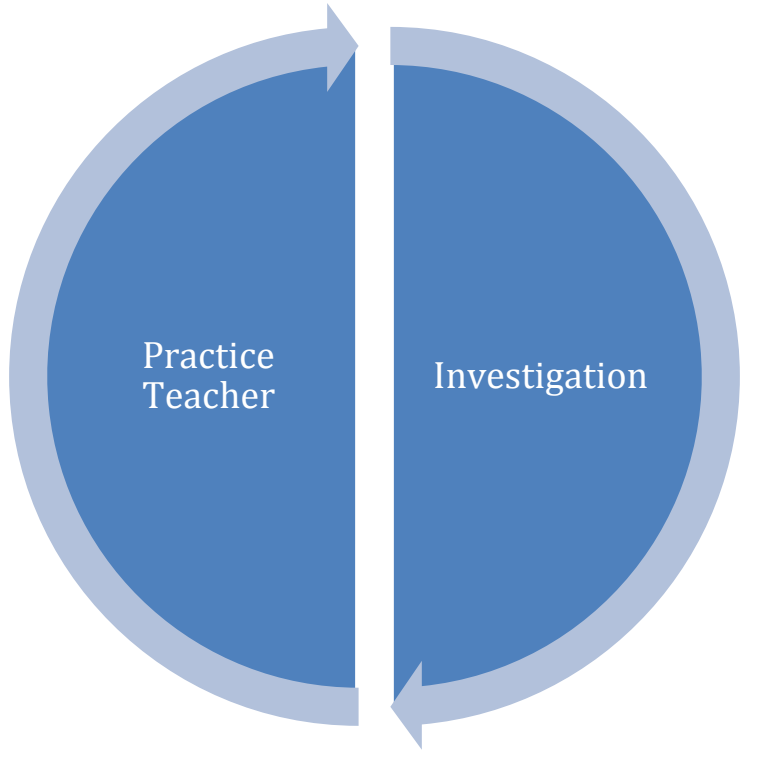

Source: María Fernanda Acosta

To sum up, both in the processes in which the class is taught and in the different moments of the researchwork on theoretical and practical learning about food and memory in different contexts and levels and from a transdisciplinary approach.

\section{Conclusions}

The teaching methodology presented is based on two pillars: research and teaching. This was built in a dialectical relationship in which these both aspects support each other. Teaching is a living practice, the same that must be thought and rethought permanently in a process of continuous improvement. In teaching, this coming and going between theory and practice is already generated through meaningful learning and practice mediated by reflexive processes. The transdisciplinary approach enriches the perspectives of students' analysis, opening space to new interpretations and reflections.

In research, these gateways are also generated between practice and theory through fieldwork. The results that are produced are new input materials for reflection in the classroom. And the new problems that are discussed in this space are potential research topics, as it is usually in pre-professional practices, which are dialogued in classrooms, where the deficiencies and needs of the educational system are visible.

This transdisciplinary teaching / researching methodology has been applied for four semesters so far, with four different groups of students and it has been possible to generate a deep and comprehensive analysis on the subject of food and knowledge. Aspects as social problems, on different levels, from the context to issues with planetary implications and the debate on food security and sovereignty are topics for debate by now. Teaching students the importance about providing children an adequate caloric intake is not enought, but it is also essential to teach other hidden factors that influence the resistance of children to eat. Initially a schoolteacher must be sensibilized and to get ready to actively listen to each child, this action will allow him or her to understand the physical and emotional aspects that may be affecting the infant. 
The general objective of the subject has been fulfilled in each semester. It has contributed to generate changes in dietary patterns in early childhood, through awareness and work with parents. The 'school for parents' space contributed to generate a joint synergy between the house and the educational centers. Based on participatory workshops, a receptive and participative attitude of the families was achieved. In these processes, it was possible to think on alternatives to improve the practices at the time of meal and also, to stablish commitments on the part of each family from Taday.

\section{Appendix 1: Cañari agrofestive calendar Source: Parish Government of San Andrés de Taday}

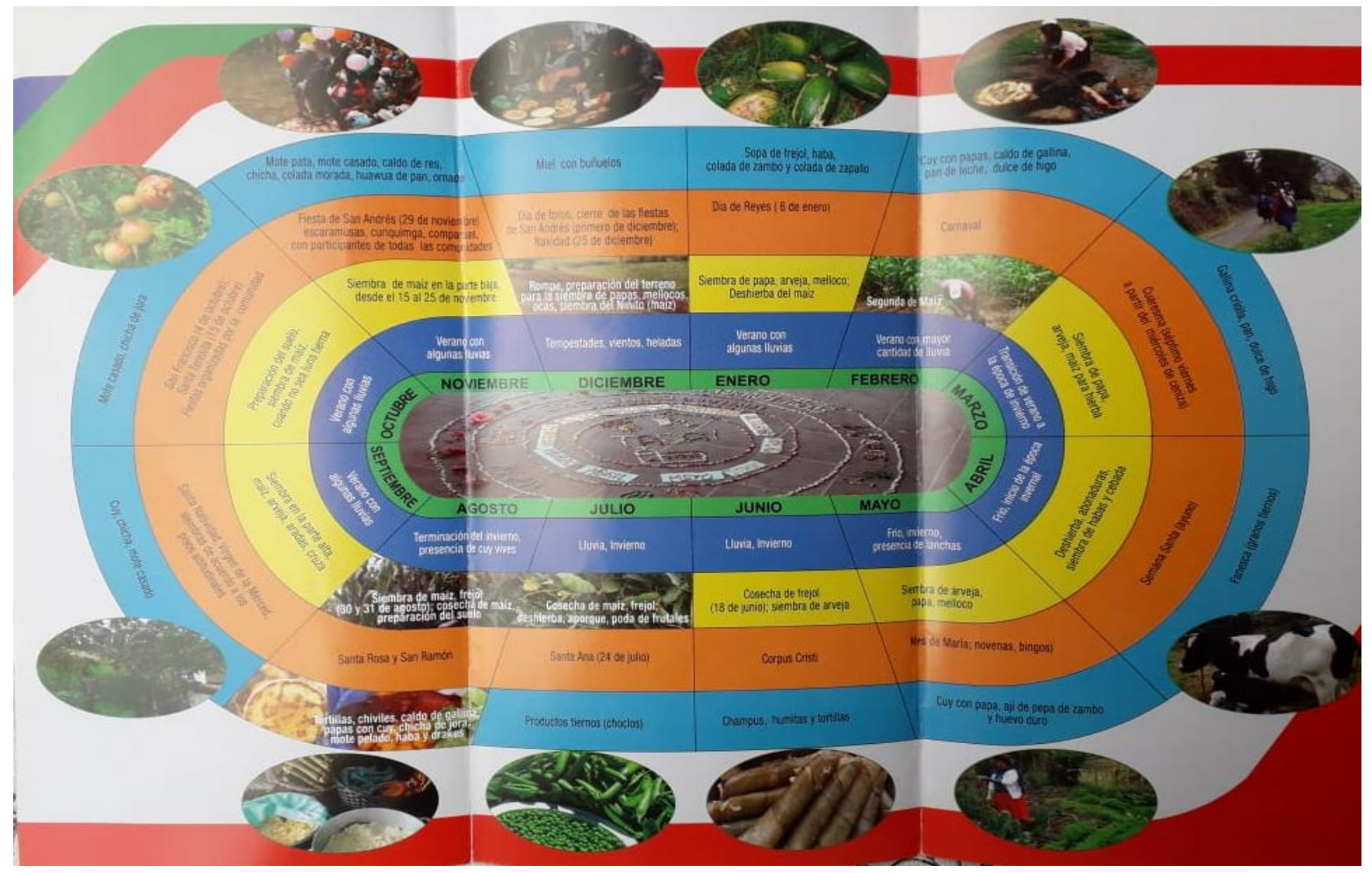

\section{Bibliografy}

Acosta Altamirano, M. F. La hora de la comida: de la balanza a la escucha afectiva. Mamakuna(5), 10-19, 2017. Obtenido de https://fr.calameo.com/read/004628483e696357f591d

De Souza Santos, B. Descolonizar el saber, reinventar el poder. Montevideo: Trilce, 2010.

Díaz-Polanco, H. Elogio de la diversidad. Globalización, multiculturalismo y etnofagía. México D.F.: Siglo XXI, 2006.

Esguerra Pérez, G., \& Guerrero Ospina, P. Estilos de aprendizaje y rendimiento académico en estudiantes de Psicología. Diversitas: Perspectivas en Psicología, 6(1), 97-109, 2010. Taken from http://www.redalyc.org/pdf/679/67916261008.pdf

Fals Borda, O. Origenes universales y retos actuales de la IAP (investigación acción participativa). Análisis Político, (38), 71-88, 1999.

Fórum mundial sobre Soberanía Alimentaria. Declaración final del Foro mundial sobre Soberanía Alimentaria, 3-7 de 09 de 2001. Taken from Socioeco.org, Sitio de recursos de la economía social y solidaria: http://base.socioeco.org/docs/doc-792_es.pdf

González, C. Mi niño no me come. Madrid: Ediciones Temas de Hoy, 2004.

Herrera, G., \& Martínez, A. (2002). Género y migración en la región del sur. Quito: FLACSO, 2004.

Gordillo, G., \& Méndez Jerónimo, O. Seguridad y soberanía alimentaria (documento base para discusión). FAO, 2013. Taken from FAO: http://www.fao.org/3/a-ax736s.pdf

Jaramillo, P. Curriculum. me, 1-97, 2001.

León Vega, X.; Malagón Zaldua, E. "Soberania alimentaria”, Centro de Documentación Hegoa, Boletín de recursos de información $n^{\circ} 5$, 2017. Taken from http://boletin.hegoa.ehu.es/mail/48 (marzo 2018)

Ochoa Moreno W. S. Migración, crecimiento y desarrollo en elEcuador. Revista Fuente Año 2, No. 3, Junio 2010.

MHPC. El tamaño del estómago y el hambre, 2010. Taken from Inapetencia infantil: http://inapetenciainfantil.blogspot.com/2010/10/el-tamano-del-estomago-y-el-hambre.html 